
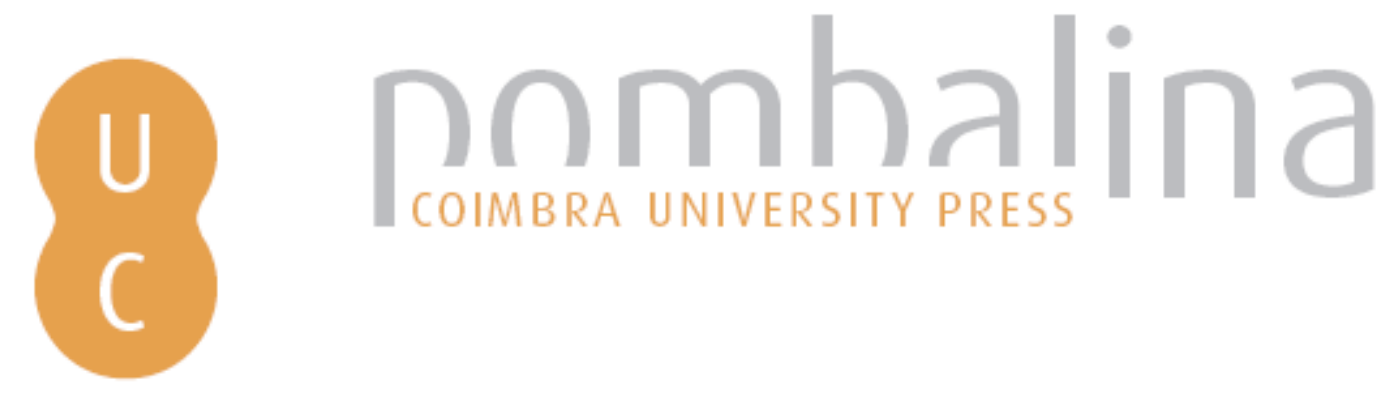

\title{
Experimental prescribed burning in Turkey oak forest of Cilento and Vallo di Diano National Park (Southern Italy): effects on vegetation and soil
}

\author{
Esposito, Assunta; Ascoli, D.; Croce, A.; Giordano, D.; Catalanotti, A. E.; \\ Autor(es): $\quad$ Mazzoleni, S.; Bovio, G.; Salgueiro, A; Palheiro, P.; Loureiro, C.; \\ Rutigliano, F. A. \\ Publicado por: Imprensa da Universidade de Coimbra \\ URL \\ persistente: \\ URI:http://hdl.handle.net/10316.2/34186 \\ DOI: \\ DOI:http://dx.doi.org/10.14195/978-989-26-0884-6_61 \\ Accessed : $\quad$ 26-Apr-2023 12:54:44
}

A navegação consulta e descarregamento dos títulos inseridos nas Bibliotecas Digitais UC Digitalis, UC Pombalina e UC Impactum, pressupõem a aceitação plena e sem reservas dos Termos e Condições de Uso destas Bibliotecas Digitais, disponíveis em https://digitalis.uc.pt/pt-pt/termos.

Conforme exposto nos referidos Termos e Condições de Uso, o descarregamento de títulos de acesso restrito requer uma licença válida de autorização devendo o utilizador aceder ao(s) documento(s) a partir de um endereço de IP da instituição detentora da supramencionada licença.

Ao utilizador é apenas permitido o descarregamento para uso pessoal, pelo que o emprego do(s) título(s) descarregado(s) para outro fim, designadamente comercial, carece de autorização do respetivo autor ou editor da obra.

Na medida em que todas as obras da UC Digitalis se encontram protegidas pelo Código do Direito de Autor e Direitos Conexos e demais legislação aplicável, toda a cópia, parcial ou total, deste documento, nos casos em que é legalmente admitida, deverá conter ou fazer-se acompanhar por este aviso.

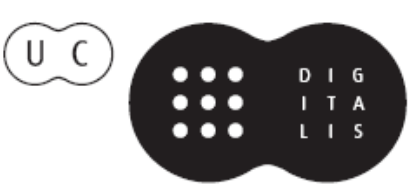




\section{ADVANCES IN}

Forest Fire

\section{RESEARCH}

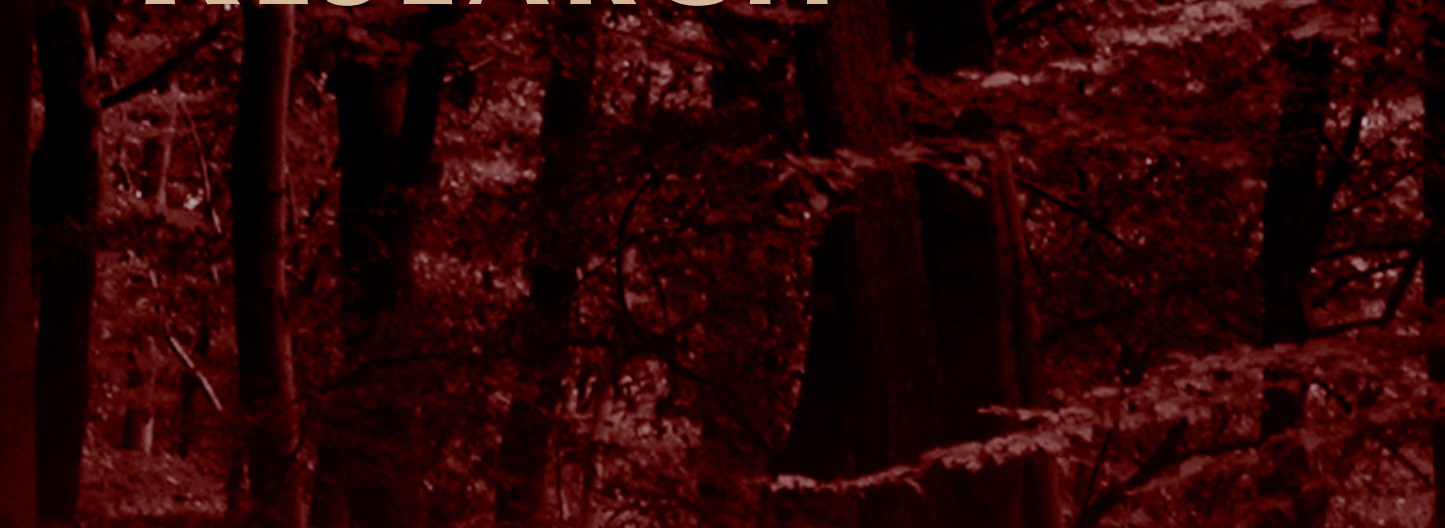

\section{DOMINGOS XAVIER VIEGAS}

\section{EDITOR}




\title{
Experimental prescribed burning in Turkey oak forest of Cilento and Vallo di Diano National Park (Southern Italy): effects on vegetation and soil
}

\author{
Assunta Esposito ${ }^{\mathrm{a}}$, Ascoli D. ${ }^{\mathrm{b}}$, Croce A. ${ }^{\mathrm{a}}$, Giordano D. ${ }^{\mathrm{c}}$, Catalanotti A.E. ${ }^{\mathrm{a}}$, Mazzoleni S. ${ }^{\mathrm{c}}$, Bovio G. $^{\mathrm{b}}$, \\ Salgueiro A ${ }^{\mathrm{d}}$, Palheiro P. ${ }^{\mathrm{d}}$, Loureiro C. ${ }^{\mathrm{d}}$, Rutigliano F.A. ${ }^{\mathrm{a}}$ \\ ${ }^{a}$ Second University of Naples, Dip.DiSTABiF, Via Vivaldi 43, 81100 Caserta, Italy, Tel.: +39 \\ 0823274544.assunta.esposito@unina2.it \\ ${ }^{b}$ University of Torino, Dip. DISAFA, Largo Paolo Braccini 2, 10095 Grugliasco, Italy \\ ${ }^{c}$ University of Naples Federico II,Dip. Agraria, Via Università 100, 80055-Portici, Italy \\ ${ }^{d}$ GIFF, Gestão Integrada de Fogos Florestais SA. Rua D. João Ribeiro Gaio, $9 B 1^{\circ}$ Esq. 4480 - \\ 811, Vila do Conde, Portugal.
}

\begin{abstract}
An experimental prescribed burn was conducted in February 2011 in a Quercus cerris forest in the Cilento e Vallo di Diano National Park (Southern Italy) to analyze fire effects on vegetation and soil.

Fuel fire behavior characteristics and were assessed to define the burning conditions that allowed a rate of fire spread between 0.10 and $0.22 \mathrm{~m} \mathrm{~min}-1$, fireline intensity never below $50 \mathrm{~kW} \mathrm{~m}-1$ and maximum flame temperatures in the litter of $600^{\circ} \mathrm{C}$ but the average residence time above $60^{\circ} \mathrm{C}$ and $300^{\circ} \mathrm{C}$ were 198 and 12 seconds, respectively. Litter fuel consumption ranged between $80 \%$ and $90 \%$.

The effect of fire on vegetation was evaluated in terms of floristic composition and structure by means of phytosociological and dendrometric samplings randomly located in burned and unburned plots two years after fire. The effect of fire on soil was evaluated by determining soil chemical $(\mathrm{pH}$, water content, total and extractable organic $\mathrm{C}$ content, total and mineral $\mathrm{N}$ ) and microbial properties (microbial biomass, soil potential respiration) in the $0-5 \mathrm{~cm}$ soil at different time since fire (3 hours, 30, 94, 209 and 394 days). Moreover, water holding capacity and bulk density were measured in burned and unburned plots at first sampling.

Results on vegetation evidenced no significant differences in species richness and diversity, in both burned and unburned plots. No changes have been found in frequency and cover values of endemic species (Digitalis micrantha, Echinops ritro subsp. siculus, Lathyrus jordanii, Teucrium siculum). Woody species showed a great resilience with very low tree mortality. Sapling persistence by high sprouting rootstocks evidenced no significant difference in the abundance of some species (Quercus cerris, Acer campestre, Carpinus betulus, Crataegus monogyna) or an increase for few species (Ruscus aculeatus, Ilex aquifolium, Erica arborea, Fraxinus ornus, Sorbus torminalis, Carpinus orientalis) in burned plots.

Results on soil showed that prescribed burning did not affect soil chemical and microbial properties, so indirect effects on plants deriving on effect of fire on soil may be excluded. Our findings highlight the sustainability of prescribed burning in Quercus cerris forests and support its future use as a management tool of fire risk reduction without significant impact on vegetation and soil.
\end{abstract}

Keywords: Quercus cerris forest, prescribed burning, biodiversity, resilience

\section{Introduction}

Fire has played an important role in shaping the distribution and composition of many biomes worldwide (Keeley et al. 2011), including temperate forests of the Northern Hemisphere (Abrams 1992; Bradshaw et al. 1997). In particular, natural and anthropogenic fire regimes have been one of the main drivers in determining life traits of oak species and the structure of oak forests in both North America (e.g., Cutter \& Guyette 1994; Shumway et al. 2001) and Europe (Clark et al. 1989; Mason 2000; Robin \& Nelle 2014). 
Oaks have several fire related traits which enable them to survive on frequent fire. Mature oaks have thicker bark than most other hardwood species (Nicolai 1986). They are capable of living for decades after bole injury. Litter displays a relatively marked flammability (Kane et al. 2008). Regeneration from root and stump sprouts can be enhanced by fire (Hutchinson 2008). A synergistic interaction of fire and masting may result in burned sites having high oak seedling density following a mast year (Brose et al. 2006; Abrams \& Johnson 2013). Fires may also kill acorn predators, which may result in increased acorn viability and germination (Johnson et al. 2002). Acorns germinate well below the soil surface where they are protected from the heat of a surface fire. The reduced shading and competition, and prepared seedbed that result from litter removal combine to provide favourable oak regeneration conditions (Wang et al. 2005).

For the above mentioned reasons, prescribed burning is broadly used to manage oak forests of North Eastern America with the objective to promote oak natural regeneration, reduce invasive species, restore biological diversity, and decrease hazardous fuel build-up (Peterson \& Reich 2001; Burton et al. 2011; Cavender-Bares \& Reich 2012; Brose et al. 2013). Such management goals are often achieved integrating prescribed burning with other sylvicultural treatments such as thinning and shelterwood cutting (Albrect \& McCarthy 2006; Brose et al. 2006).

Several oak species of Northern America managed by prescribed burning (i.e. Quercus alba, $Q$. ellipsoidalis, $Q$. macrocarpa, $Q$. marilandica, $Q$. rubra, $Q$. shumardii, $Q$. stellata), are vicariant of main European oak species, e.g., $Q$. alba vs. $Q$. petraea, $Q$. macrocarpa vs. $Q$. robur, $Q$. stellata vs. Q. cerris (Box \& Manthei 2005), with which share similar ecological traits and regeneration strategies. However, the use of prescribed burning for forest management goals has been relatively recent in Europe in comparison to North America (Fernandes et al. 2013).In particular, very little knowledge exists regarding prescribed fire behaviour and its ecological effects in deciduous oak forests of Europe. In order to assess the ecological sustainability of this management practice, investigations are needed to reduce undesirable fire effects on the ecosystem components, such as tree seedlings mortality, soil degradation and floristic impoverishment (Franklin et al. 2003; Hutchinson et al. 2005; Neary et al. 2010; Williams et al. 2012).

With these aims, an experimental prescribed burning was carried out in 2011 in a Quercus cerris forest of the Cilento e Vallo di Diano National Park, Southern Italy (Ascoli et al. 2012). Since this forest is located in a Site of Community Importance (IT8050002 included in Annex I of the Directive $92 / 43 / E E C)$, ecological monitoring was particularly important in order to evaluate the effects on biodiversity and to exclude possible negative impact to holly (Ilex aquifolium) and ruscus (Ruscus aculeatus), being both species protected by a regional law.

In particular the specific objectives of the present study are: i) to characterize fuels and fire behaviour observed during the experimental prescribed burning; ii) to assess short term effects of fire on understory plant species diversity, oak regeneration andprotected plant species ; iii) to analyse fire effects on soil chemical and microbial properties.

\section{Methods}

\subsection{Study area}

The study site $\left(40^{\circ} 17^{\prime} 10^{\prime \prime} \mathrm{N} ; 5^{\circ} 16^{\prime} 51^{\prime}\right.$ 'E) is located in the National Park of Cilento, Vallo di Diano and Alburni, Sothern Italy (Figure 1), about $20 \mathrm{~km}$ apart from the sea in a hilly area. The site is $455 \mathrm{~m}$ a.s.l., with a SW aspect and an average of $40 \%$ slope. The climate is mesotemperate humid with mean annual temperature of $14.7^{\circ} \mathrm{C}$ (ranging from $6.3^{\circ} \mathrm{C}$ in January to $23.6^{\circ} \mathrm{C}$ in August) and annual precipitation of $825 \mathrm{~mm}$ with a dry period in summer with less than $100 \mathrm{~mm}$. (Gioi meteorological station, $684 \mathrm{~m}$ a.s.1., $22 \mathrm{~km}$ apart from the study site).

Soil is Calcari-Vertic Cambisols and geologic substrate is Marls and Calcarenites of the Stream Trenico of the Chattian (FAO 1998; di Gennaro, 2002). 
Vegetation is characterized by Quercus cerris wood 14-16 m high with an average cover of $80 \%$ and a low scattered presence of Sorbus domestica, Ostrya carpinifolia e Fraxinus ornus. The woody understorey is dominated by Carpinus orientalis, Crataegus monogyna, Ilex aquifolium, Ruscus aculeatus and Erica arborea, whereas the main representative herbs are Festuca exaltata, Echinops ritro subsp. siculus, Digitalis micrantha.

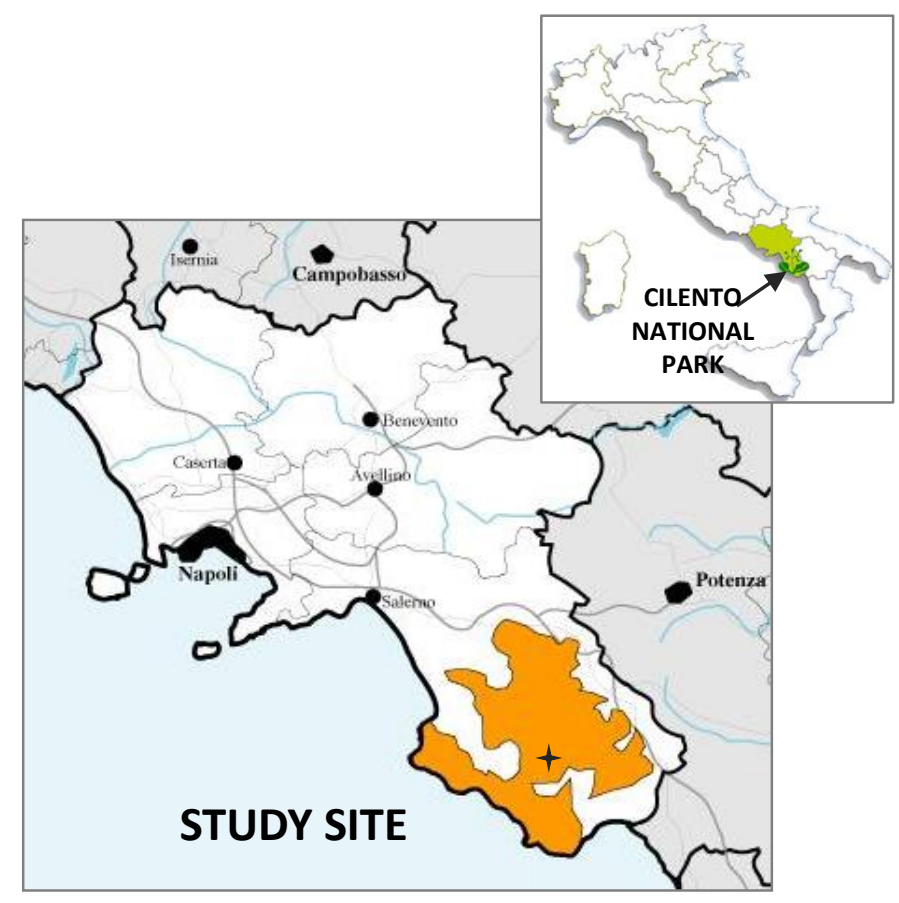

Figure 1. Study site location

\subsection{Fuel and prescribed fire characterization}

The prescribed burn was conducted in winter 2011 on an area of 0.7 ha. Fuel characteristics were assessed few days before burning. Dead fine $(<6 \mathrm{~mm})$ surface fuels were constituted by $Q$. cerris litter, cured grasses and dead woody material. Live grasses and forbs, and elevated live woody fuels such as Erica arborea, were sparse. Dead surface fuels were harvested in six $1 \mathrm{~m}^{2}$ quadrats and dried in the laboratory to determine the fuel load. Fuel bed depth and cover of dead fuels were also measured every $0.5 \mathrm{~m}$ along six linear transects $(10 \mathrm{~m})$.Dead fine fuel moisture was assessed at the time of the burn by collecting 5 litter samples. Fresh samples (50 g each) were weighed in the field by a portable scale, and then dried in laboratory.

Fire behaviour was assessed at a microplot scale (Fernandes et al. 2001) by measuring the arrival time of the fire front at the vertices of a triangle and computing the rate of spread according to the trigonometric method of Simard et al. (1984). Five equilateral triangles (2 m side) were visualized using $2 \mathrm{~m}$ rods placed at each triangle vertex. The time of arrival of the fire front was measured using K-Type thermocouples $(0.4 \mathrm{~mm})$ positioned at each triangle vertex within the litter fuel $(5 \mathrm{~cm}$ from the soil surface), and connected to a data-logger buried one meter apart. Flame temperature was measured every second during all combustion phases. Flame height was assessed by two observers which used as a reference scale the increment markers $(0.5 \mathrm{~m})$ painted on each rod. Fireline intensity was calculated using the Byram (1959) formula applying a high heat content of $20000 \mathrm{~kJ} \mathrm{~kg}^{-1}$. Air temperature and moisture, and wind speed and direction were assessed every time fire was spreading through a triangle using a portable weather stations positioned at midflame height at a distance of $5 \mathrm{~m}$ upwind the triangle. In total, 5 rate of spread observations and 15 time-temperature profiles were collected. Fuel consumption was assessed soon after the fire by harvesting remaining charred fuels in a $1 \mathrm{~m}^{2}$ quadrat within the triangle. 


\subsection{Vegetation sampling}

The effects of prescribed burning were assessed in summer 2013 to analyze the following parameters: floristic and structural composition, plant community sintaxonomy, species richness, species density, demography and regeneration of structural species. Plant community was sampled by the phytosociological method (Braun-Blanquet, 1964) on sampling area of $100 \mathrm{~m}^{2}$ for sintaxonomical characterization. Moreover the phytosociological method was applied on $1 \mathrm{~m}^{2}$ sampling plots along randomly located transects to analyze the effects of burning application on plant biodiversity. In total, 40 plots were surveyed in both burned and control sites. Thesurvey was carried outin accordance with theBraun-Blanquet scale and then converted in Van der Maarel (1979) scale in the data matrix.

The data matrix (60 species x 80 relevés) was analyzed by Principal Component Analysis (PCA) with algorithm Euclidean distance contained in SYN-TAX package (Podani, 2001) to test the degree of floristical similarity between burned and control plots. The software EstimateS (Colwell, 2013) was used to calculate rarefaction curve of richness estimators and biodiversity for sample based data (40 burned plots and 40 control plots). The nomenclature of species follows Pignatti (1982), Med Check list (Greuter et al., 1989), and Conti et al. (2005, 2007).

Stand structure (tree species density, basal area, height, and status: alive, dead, fallen, fire scar) was also assessed. Trees with a diameter at breast height $>5$ cmwere measured in a circular plot of $20 \mathrm{~m}$ in diameter. Tree regeneration with a diameter $<5 \mathrm{~cm}$ and a height $>30 \mathrm{~cm}$ was assessed in a circular plot of $8 \mathrm{~m}$ in diameter. Regeneration with a height $<30 \mathrm{~cm}$ was assessed in the same plot used for phytosociological relevés. Regeneration was characterized by stem density, height and status (live/dead; seedling, sapling, post-fire sprout). For each plot, environmental data such as slope, litter cover and depth, bare soil, rocks, herb and shrub cover and height) were also recorded to evaluate their potential effects. A total of 40 plots were surveyed in both burn and control sites. Statistical analysis was performed to evaluate significant differences of individual number (test $\mathrm{Chi}^{2}$ ) and average height (test U-Mann-Whitney) between burned and control plots.

\subsection{Soil collection and analysis}

To evaluate the effect of prescribed burning on soil properties that could affect oak, soil samples were collected at $0-5 \mathrm{~cm}$ depth in 6 randomly selected sub-plots $(40 \times 40 \mathrm{~cm})$ of burned and unburned plots at different times since burn (3 hours, 30, 94, 209 and 394 days).

In the first sampling, in both control and burned plots, soil water holding capacity and bulk density were determined by gravimetric method (USDA, 2004). At each sampling time sieved soil samples (2-mm mesh) were analysed for chemical (water content, $\mathrm{pH}$, total organic $\mathrm{C}$, extractable organic $\mathrm{C}$, total $\mathrm{N}$, ammoniacal $\mathrm{N}$ and nitric $\mathrm{N}$ ) and microbial properties (microbial $\mathrm{C}$ and soil potential respiration).

Water content was measured by gravimetric method (Allen, 1989). Soil pH was determined by potentiometric method on air dried soil:water suspension with a 1:2.5 ratio using a calibrated electrode (Hanna Instruments mod. HI1230). Total organic carbon content was measured on air dried soil by humid oxidation method (Springer and Klee, 1954). Extractable and microbial C were determined on fresh soil by chloroform-fumigation extraction method (Vance et al., 1987). Total $\mathrm{N}$ was determined with NCS Elemental Analyser (ThermoFlash EA 1112). The ammonium and nitrate contents were determined by potentiometric method (Beck, 1993) on fresh soil stored at $4{ }^{\circ} \mathrm{C}$ until measurement, by using specific potentiometric electrode for ammonia (ORION, Mod. 9512BNWP) and one specific for nitrate (ORION, Mod. 290A) after Castaldi and Aragosa (2002). Soil potential respiration, indicating microbial activity, was determined measuring, by gas chromatography, $\mathrm{CO}_{2}$ evolved from samples incubated in standard conditions $\left(25^{\circ} \mathrm{C}, 55 \%\right.$ of water holding capacity, in the dark) for one hour (Kieft et al., 1998). 


\section{Results}

\subsection{Fuel characteristics and prescribed fire behaviour}

Pre-fire fuel cover was 100\%.Mean fuel bed depth was $8 \mathrm{~cm}$. Dead fine fuel load ranged between 3.4 and $5.7 \mathrm{t} \mathrm{ha}^{-1}$. During the burn, mean fine dead fuel moisture content (dry weight basis) was $38 \%$ (Table 1).Weather conditions are reported in Table 1.

Table 1-Mean weather, fuels and fire behavior characteristics observed during an experimental prescribed burning in Quercus cerris litter fuels. Photos shows prescribed fire behavior and fuel consumption.

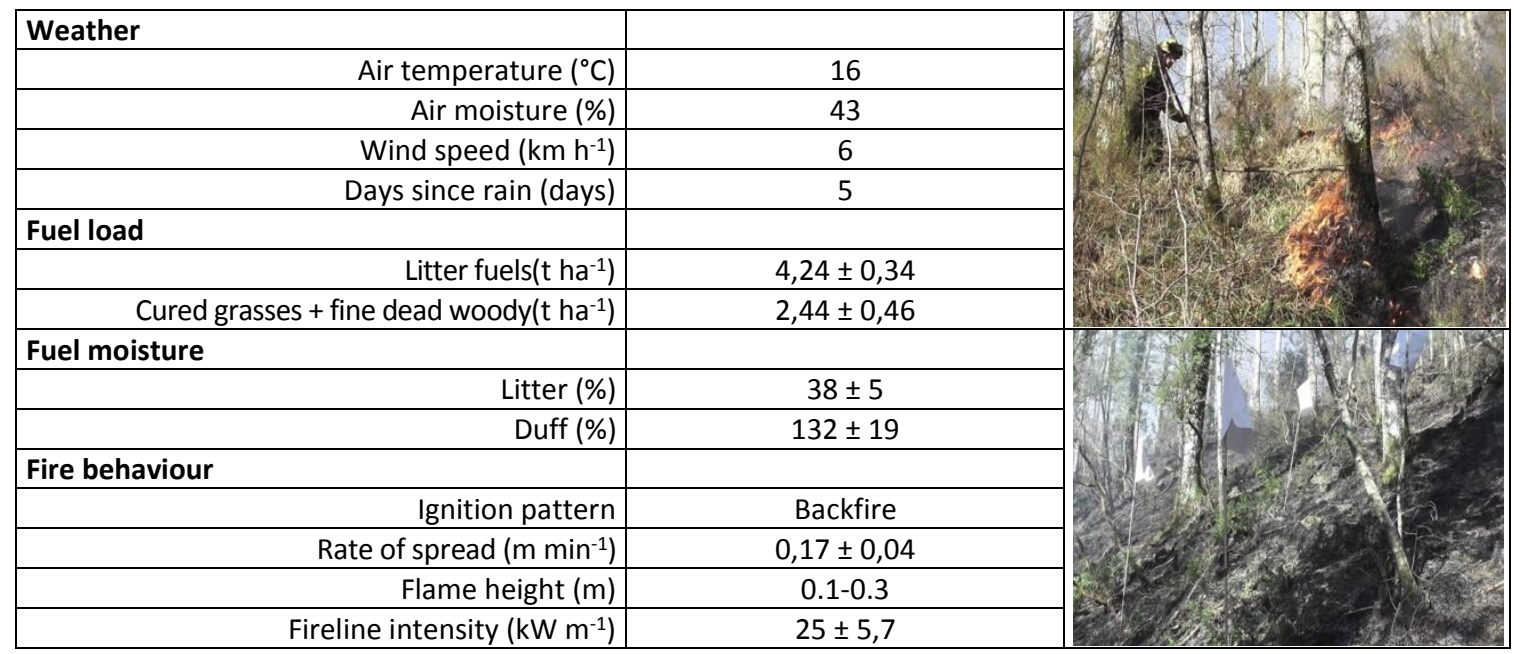

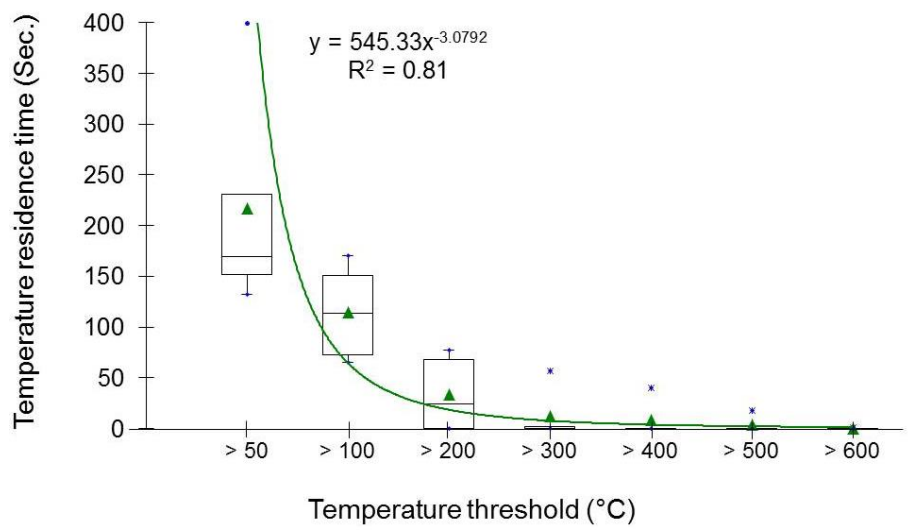

Figure 2. Flame temperature residence time above threshold temperatures measured at the soil surface during a prescribed burning in $Q$. cerris litter fuels.Boxes show the first and third quartiles; the black line is the median.Green triangles are the mean.Negative exponential function, its equation and $\mathbf{R} 2$ are also displayed.

Fire rate of spread varied between 0.10 and $0.22 \mathrm{~m} \mathrm{~min}^{-1}$. Fuel consumption ranged between 80 and $90 \%$ of the pre-fire mean fuel load (see figure in Table 1). Maximum flame temperature ranged between $159^{\circ} \mathrm{C}$ and $601^{\circ} \mathrm{C}$. Average residence time above $60^{\circ} \mathrm{C}$ and $300^{\circ} \mathrm{C}$ were 198 and 12 seconds, respectively. Figure 2 shows the flame temperature residence time above threshold temperatures measured at the soil surface. The temperature decay displayed a negative exponential function.

\subsection{Vegetation}

On the basis of phytosociological relevés the studied forest formations can be classified as part of mesotemperate Quercus cerris wood, referring to the association Lathyro digitati quercetum cerridis Bonin and Gamisans 1976 and subassociation festucetosum exaltata (Rosati et al.2005). These forestsare distributed in the clay-marl and sandstone areas of hilly and mountain between 400 and 850 $\mathrm{m}$ a.s.l. and are referred to suballiance Ptilostemo-Quercenion cerridis (Teucrio siculi-Quercion cerridis). Burned and control area show a great homogeneity in the floristic composition especially 
highlighted by the high number of species frequency $\mathrm{V}$ (at least $80 \%$ of the relevès). In the phytosociological relevés all the species characteristic of association (Lathyrus jordanii, Carpinus orientalis, Ptilostemon strictus and Melittis melissophyllum), were found while between the characteristics of sub-association Erica arborea and Drymochloa drymeja are very common.

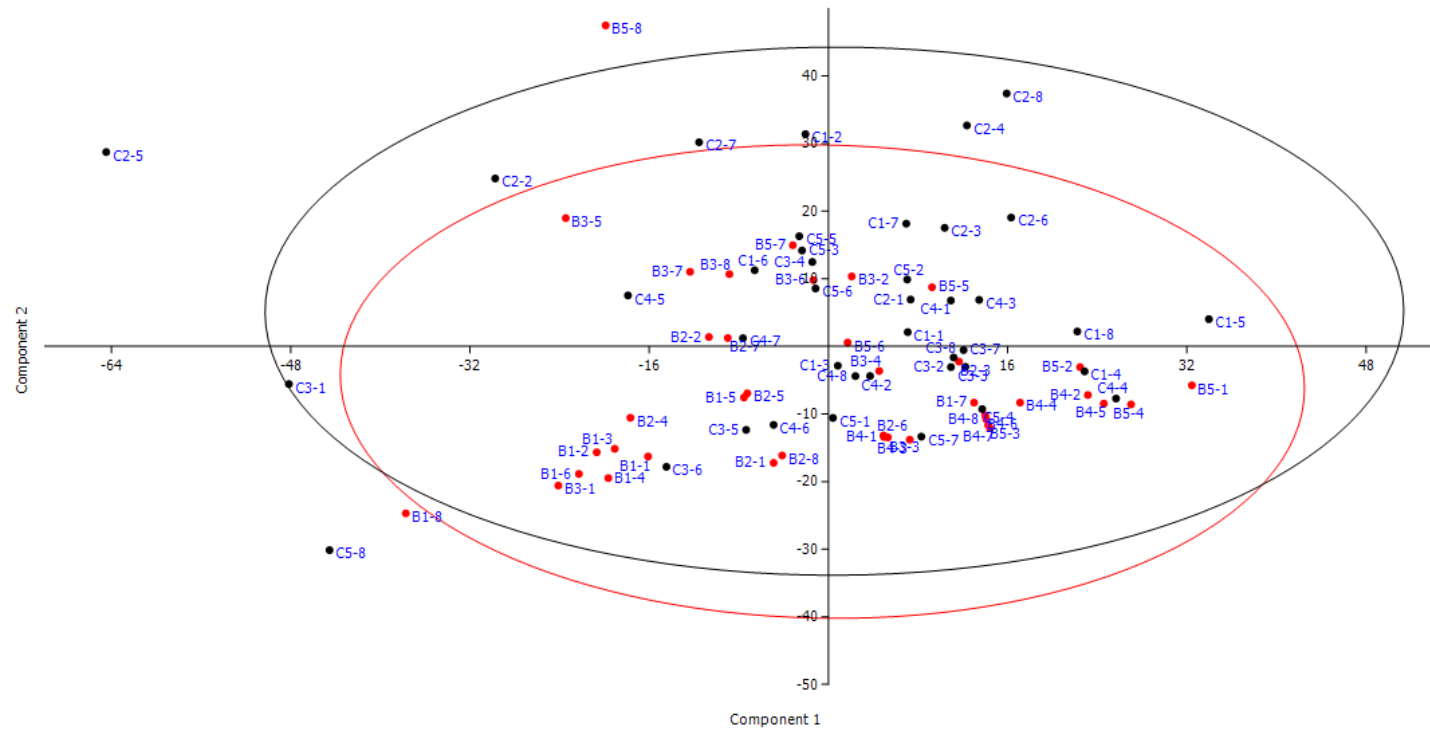

Figure 3. Principal Component Analysis of sampled 80 plots in burned (red) and control (black)area.

The prescribed burning did not affect the understory floristic composition as showed in the Figure 3. The PCA obtained by the analysis of a data matrix (60 species x 80 relevès) does not show a clear separation of burned and control plots along the axis 1 and 2 (explaining35\%of the total variability). The ellipses enclose $95 \%$ of the variability and are strongly overlapping.

Prescribed burning did not affect the understory plant biodiversity. The rarefaction curve of richness estimators and biodiversity for sample based data (40 burned plots and 40 control plots) showed a similar pattern of variation with a not significant distance. In fact, considering the $95 \%$ confidence limits, the curves are superimposed (Figure 4A). No changes were found also in species density as reported in Figure 4B that evidence the same values in the average species number in both treatments.
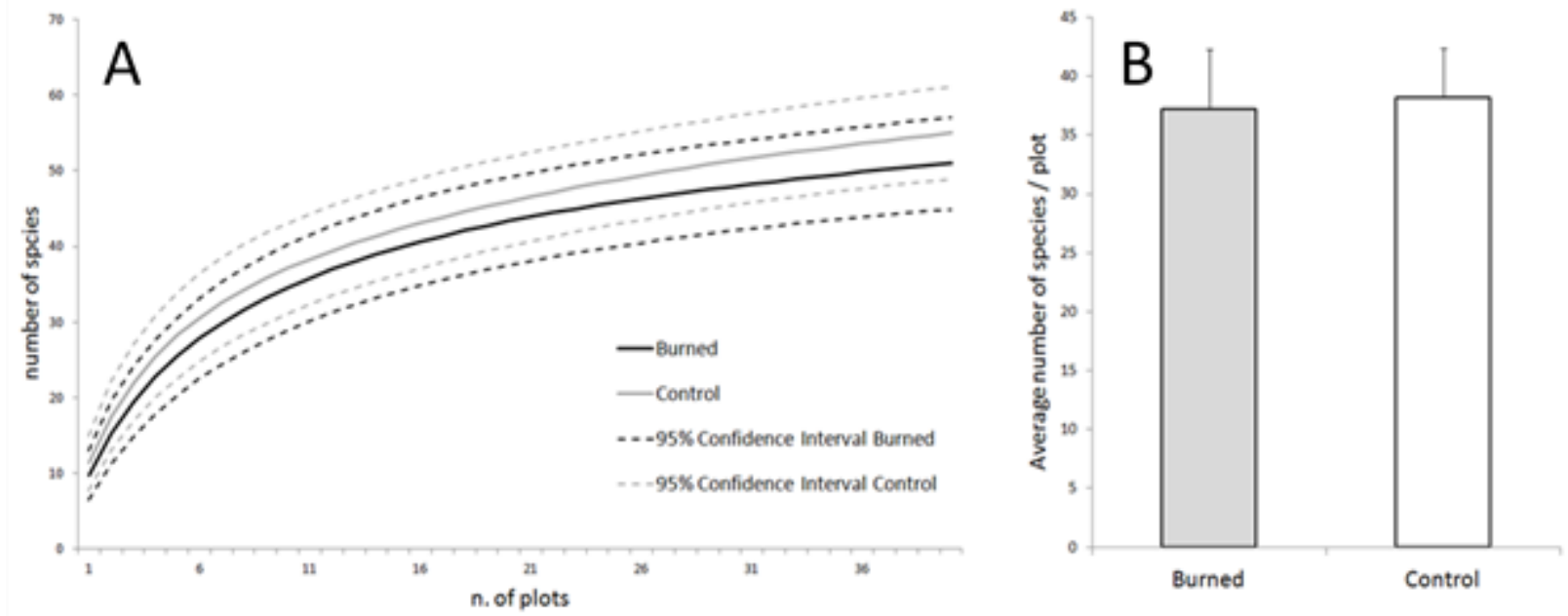

Figure 4. Rarefaction curve of species richness (A) and Average number of species/plot in burned and control area (B). 
The analysis of the regeneration was carried out on all tree species present in both seedling and the sapling state. As showed in Table 2 the burning treatment produced a different effect in relation to life trait of species. In particular, Erica arborea, Fraxinus ornus, Ilex aquifolium, and Sorbus torminalis evidenced a significant increase of individual number in burned area while $S$. domestica show a decrease.

Table 3. Total number of individuals and average height of woody species in burned and control area. For each species significant differences between burned and unburned are reported $(n . s .=$ not significant; $*=p<0,05 ; * *=$

\begin{tabular}{|l|c|c|c|c|c|c|}
\cline { 2 - 8 } \multicolumn{1}{c|}{} & \multicolumn{3}{c|}{ Number of individuals } & \multicolumn{3}{c|}{ Average height ( \pm STD) } \\
\hline \multicolumn{1}{|c|}{ Species } & Burned & Control & test X & Burned & Control & U test \\
\hline Acer campestre & 17 & 13 & n.s. & $0.39( \pm 0.09)$ & $0.65( \pm 0.34)$ & n.s. \\
\hline Carpinus betulus & 20 & 32 & n.s. & $0.99( \pm 0.29)$ & $0.81( \pm 0.32)$ & n.s. \\
\hline Carpinus orientalis & 37 & 49 & n.s. & $0.51( \pm 0.23)$ & $0.85( \pm 0.39)$ & $* * *$ \\
\hline Crataegus monogyna & 25 & 27 & n.s. & $0.63( \pm 0.33)$ & $0.56( \pm 0.23)$ & n.s. \\
\hline Erica arborea & 194 & 45 & n.s. & $0.62( \pm 0.22)$ & $0.90( \pm 0.34)$ & $* * *$ \\
\hline Fraxinus ornus & 304 & 169 & $* * *$ & $0.46( \pm 0.16)$ & $0.63( \pm 0.30)$ & $* * *$ \\
\hline Ilex aquifolium & 65 & 20 & $* * *$ & $0.58( \pm 0.26)$ & $0.58( \pm 0.31)$ & n.s. \\
\hline Quercus cerris & 177 & 202 & n.s. & $0.43( \pm 0.24)$ & $0.40( \pm 0.10)$ & $* *$ \\
\hline Sorbus domestica & 6 & 15 & $*$ & $0.50( \pm 0.00)$ & $0.47( \pm 0.12)$ & n.s. \\
\hline Sorbus torminalis & 27 & 7 & $* * *$ & $0.51( \pm 0.16)$ & $0.55( \pm 0.17)$ & n.s. \\
\hline
\end{tabular}

The ability to survive burning treatment with vegetative regrowth was found particularly interesting both in the structural species Quercus cerris but especially in some species of conservation interest as Ruscus aculeatus and Ilex aquifolium. These species responded to burning by resprouting from both the stem and the rhizome (Figure 5).

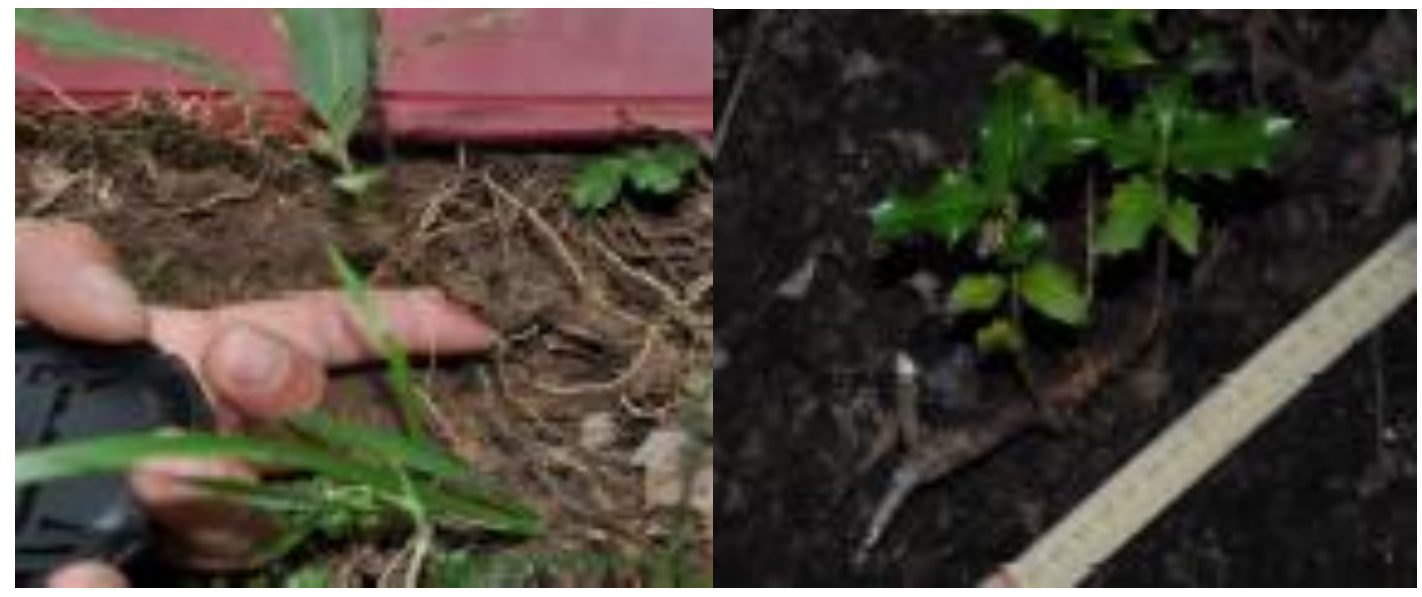

Figure 5. Regrowth after prescribed burning in Quercus cerris seedlings (right) and Ilex aquifolium (left).

\subsection{Effects on soil}

Results show that soil samples collected in control and burned plots did not affect soil water holding capacity or bulk density (Table 4).

Soil chemical and microbial properties determined at different times in burned and unburned plots showed that sampling time is the main factor affecting properties of soil compared to fire (Table 5, Figure 6). In fact, all parameters were significantly ( $\mathrm{P}<0.05$; two-way ANOVA) affected by sampling time, except for soil $\mathrm{pH}$ and total $\mathrm{N}$, probably because of temporal variation of climatic conditions. By 
contrast, only nitric $\mathrm{N}$ appeared significantly ( $\mathrm{P}<0.05$; two-way ANOVA) affected by fire. It has to be underlined that accidental changes of some parameters ( $\mathrm{pH}$, water content and nitric $\mathrm{N}$ ), observed only much time after prescribed fire (Table 5), did not appear due to fire treatment. It is not surprising that no effect on soil was found because litter surface temperature was higher than $100^{\circ} \mathrm{C}$ only for 114 seconds. Similarly, Tecimen and Sevgi (2011) found no effect on C or N fractions if soil from Quercus forests $\left(Q\right.$. petrea, $Q$. robur, $Q$. frainetto and $Q$. cerris) was heated until to $100{ }^{\circ} \mathrm{C}$ for $1-4 \mathrm{~h}$, whereas a loss of $\mathrm{C}$ content and an increase in ammoniacal $\mathrm{N}$ were observed at higher temperature.

Table 4. Mean values ( \pm standard deviations) of water holding capacity and bulk density of soil determined in the first sampling (February 2011) in burned and unburned plots of Q. cerris stand.

\begin{tabular}{ccc}
\hline Treatment & $\begin{array}{c}\text { Water holding } \\
\text { Capacity(\%) }\end{array}$ & $\begin{array}{c}\text { Bulk density } \\
\left(\mathbf{k g ~ m}^{-3}\right)\end{array}$ \\
\hline Control & $41.5( \pm 11.0)$ & $0.94( \pm 0.2)$ \\
Burned & $45.7( \pm 16.0)$ & $0.95( \pm 0.2)$ \\
\hline
\end{tabular}

Table 5. Mean values ( \pm standard deviations) of soil $p H$, water content, total $N\left(N_{t o t}\right)$, ammoniacal $N\left(N H_{4}{ }^{+}-N\right)$ and nitric $\mathrm{N}\left(\mathrm{NO}_{3}-\mathrm{N}\right)$ in burned and unburned plots of $Q$. cerris stand at different sampling times. For each sampling date significant differences (one-way ANOVA) between burned and unburned are reported $(* P<0.05: * * P<0.01)$.

\begin{tabular}{|c|c|c|c|c|c|}
\hline $\begin{array}{l}\text { Sampling date } \\
\text { (times after fire) } \\
\text { Treatment }\end{array}$ & $\mathrm{pH}$ & $\begin{array}{l}\text { Water } \\
\text { content (\% } \\
\text { d.w.) }\end{array}$ & $\begin{array}{c}N_{\text {tot }} \\
\left(\mu \mathrm{g} \mathrm{g}^{-1}\right)\end{array}$ & $\begin{array}{l}\mathrm{NH}_{4}{ }^{+}-\mathrm{N} \\
\left(\mu \mathrm{g} \mathrm{g}^{-1}\right)\end{array}$ & $\begin{array}{l}\mathrm{NO}_{3}^{-}-\mathrm{N} \\
\left(\mu \mathrm{g} \mathrm{g}^{-1}\right)\end{array}$ \\
\hline \multicolumn{6}{|l|}{$8 / 2 / 2011(3 h)$} \\
\hline Control & $5.5( \pm 0.5)$ & $63.0( \pm 19.1)$ & $6.1( \pm 1.8)$ & $74.1( \pm 35.6)$ & $2.1( \pm 1.2)$ \\
\hline Burned & $5.6( \pm 1.0)$ & $63.5( \pm 9.4)$ & $7.0( \pm 2.2)$ & $68.1( \pm 30.8)$ & $7.7( \pm 8.3)$ \\
\hline \multicolumn{6}{|l|}{$10 / 3 / 2011(30 d)$} \\
\hline Control & $5.4( \pm 0.5)$ & $73.5( \pm 18.8)$ & $7.7( \pm 2.0)$ & $52.0( \pm 34.8)$ & $1.9( \pm 0.6)$ \\
\hline Burned & $5.6( \pm 0.6)$ & $62.1( \pm 13.9)$ & $5.7( \pm 1.7)$ & $45.3( \pm 9.4)$ & $2.6( \pm 1.4)$ \\
\hline \multicolumn{6}{|l|}{$13 / 5 / 2011(94 d)$} \\
\hline Control & $5.7( \pm 0.5)$ & $50.4( \pm 4.8)$ & $5.7( \pm 1.0)$ & $44.8( \pm 17.2)$ & $1.8( \pm 1.9)$ \\
\hline Burned & $6.5( \pm 0.4)^{*}$ & $42.7( \pm 2.7)^{* *}$ & $6.6( \pm 0.6)$ & $45.1( \pm 13.0)$ & $7.8( \pm 5.2)^{*}$ \\
\hline \multicolumn{6}{|l|}{$16 / 9 / 2011(209 d)$} \\
\hline Control & $6.1( \pm 0.9)$ & $25.2( \pm 3.1)$ & $6.7( \pm 1.5)$ & $8.1( \pm 2.3)$ & $0.2( \pm 0.2)$ \\
\hline Burned & $5.4( \pm 0.6)$ & $27.3( \pm 8.0)$ & $6.1( \pm 0.9)$ & $9.0( \pm 3.5)$ & $0.1( \pm 0.1)$ \\
\hline \multicolumn{6}{|l|}{$8 / 03 / 2012$ (394 d) } \\
\hline Control & $5.0( \pm 0.4)$ & $59.1( \pm 9.1)$ & $6.3( \pm 1.3)$ & $21.1( \pm 8.5)$ & 0 \\
\hline Burned & $4.7( \pm 0.6)$ & $44.9( \pm 11.0)^{* *}$ & $4.7( \pm 1.4)$ & $13.6( \pm 7.0)$ & 0 \\
\hline
\end{tabular}



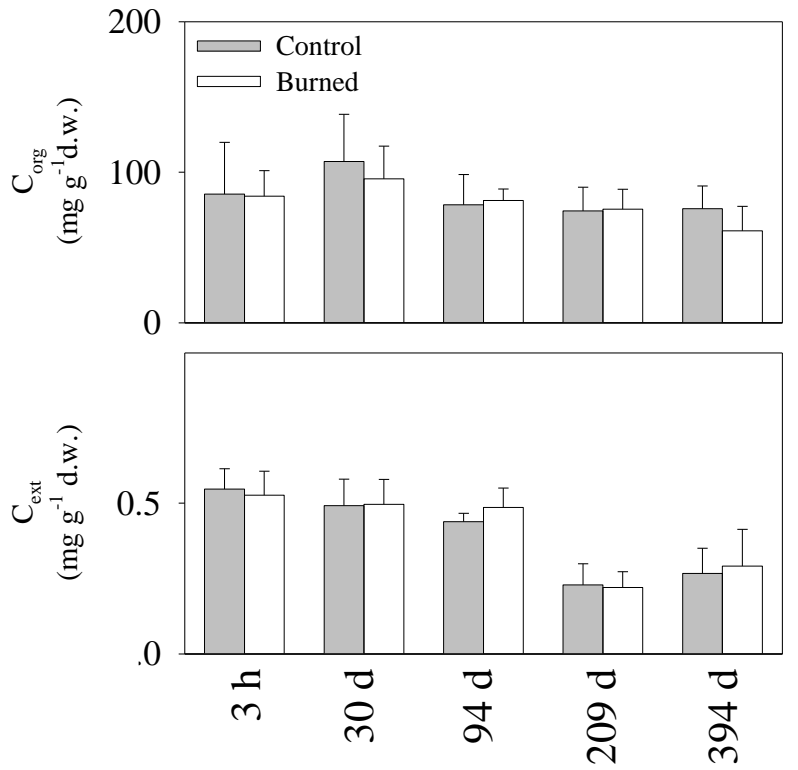

Time after fire
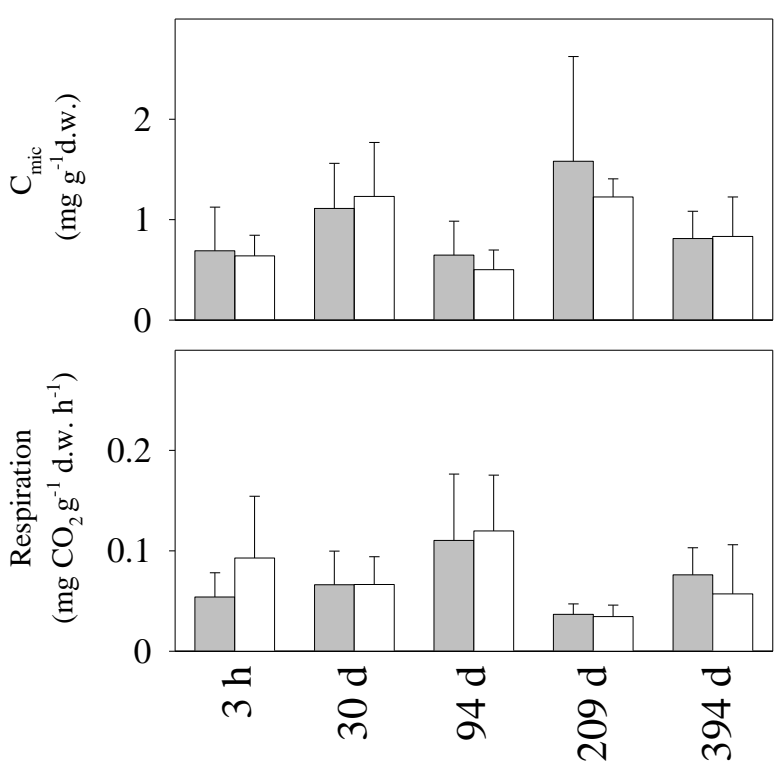

Time after fire

Figure 6. Mean values (+ standard deviations) of soil total organic $C\left(\boldsymbol{C}_{\text {org }}\right)$, extractable organic $C\left(\boldsymbol{C}_{\text {ext }}\right)$, microbial $C$ $\left(C_{m i c}\right)$ and respirationin burned and unburned (control) plots.

\section{Conclusion}

In the studied Quercus cerris forest (Lathyro digitati quercetum cerridis-subassociation festucetosum exaltata) the prescribed burning application did not affect vegetation and soil during the two year after treatment. No significant changes occurred in floristic composition, species richness and density. The structural species Quercus cerris and some interesting protected taxa (Ruscus aculeatus and Ilex aquifolium) evidenced a high regeneration ability by regrowth of killed stem through resprouting new young shoot.

Moreover changes in soil chemical and microbial parameters due to fire were generally not significant and smaller than those occurring during the year, suggesting that fire-induced changes do not overcome the natural temporal variability of these parameters.

Our first results highlight the sustainability of prescribed burning in Quercus cerris forests as a management tool both in fire risk reduction and quercus cerris regeneration. Further monitoring activities should be continued to know the impact on all ecosystem components in the medium and long term and to evaluate the most appropriate burning prescriptions and time of frequency application.

\section{References}

Abrams M.D., 1992. Fire and the development of oak forests. Bioscience 42(5): 346-353.

Abrams M.D., Johnson S.E., 2013. The Impacts of Mast Year and Prescribed Fires on Tree Regeneration in Oak Forests at the Mohonk Preserve, Southeastern New York. Natural Areas Journal 33(4): 427-434.

Albrecht M.A, Brian C. McCarthy B.C., 2006. Effects of prescribed fire and thinning on tree recruitment patterns in central hardwood forests. Forest Ecology and Management 226: 88-103. Allen S.E., 1989. Chemical analysis of ecological materials. Blackwell Scientific Publications, Oxford. 
Ascoli D., Catalanotti A., Valese E., Cabiddu S., Delogu G., Driussi M., Esposito A., Leone V., Lovreglio R., Marchi E., Mazzoleni S., Rutigliano F.A., Strumia S., Bovio G., 2012. Esperienze di fuoco prescritto in Italia: un approccio integrato per la prevenzione degli incendi. Forest@ 9: 2038.

Beck T., 1993. Die N-Mineralisation von Boden im Laborbrutversuch Z. Plflanzenernaehr Bodenkd. Vol. 146, pp. 243-252.

Bradshaw R.H.W., Tolonen K., Tolonen M., 1997. Holocene records of fire from the boreal and temperate zones of Europe. Sediment Records Biomass Burning and Global Change. NATO ASI Series 51: 347-365.

Braun Blanquet 1964. Pflanzensociologie: Grundzuge der Vegetationskunde. 3te aufl. SpringerVerlag, Wein. 865 pp.

Brose P.H., Shuler T.M., Ward J.S., 2006. Responses of Oak and Other Hardwood Regeneration to Prescribed Fire: What We Know as of 2005. GTR-NRS-P-1, 123-135.

Brose P.H., Dey D.C., Phillips R.J., Waldrop T.A., 2013. A Meta-Analysis of the Fire-Oak Hypothesis: Does Prescribed Burning Promote Oak Reproduction in Eastern North America? Forest Science 59(3): 322-334.

Box E.O., Manthey M., 2005. Oak and other deciduous forest types of Eastern North America and Europe. Botanika Chronika 18(1): 51-62.

Burton J.A., Hallgren S.W., Fuhlendorf S.D., Leslie D.M., 2011. Understory response to varying fire frequencies after 20 years of prescribed burning in an upland oak forest. Plant Ecology 212: 15131525 .

Byram G.M., 1959. Combustion of forest fuels. In 'Forest Fire: Control and Use'. (Eds AA Brown, KP Davis) pp. 61-89. (McGraw-Hill Book Company: NewYork)

Castaldi S., Aragosa D., 2002. Factors influencing nitrification and denitrification variability in a natural and fire-disturbed Mediterranean shrubland. Biology and Fertility of Soils 36: 418-425.

Cavender-Bares J., Reich P.B., 2012. Shocks to the system: community assembly of the oak savannain a 40-year fire frequency experiment. Ecology 93(8): S52-S69.

Cutter B.E., Guyette R.P., 1994. Fire Frequency on an Oak-Hickory Ridgetop in the Missouri Ozarks American Midland Naturalist 132(2): 393-398.

Clark J., Merkt J., Muller H., 1989. Post-glacial fire, vegetation and human history on the northern Alpine forelands, south-western Germany. Journal Ecology 77: 897-925.

Colwell R.K., 2013. EstimateS: Statistical estimation of species richness and shared species from samples.Version 9 and earlier. User's Guide and application. http:/viceroy.eeb.uconn.edu/EstimateS

Conti F., Abbate G., Alessandrini A., Blasi C. (eds.), 2005. An annotated check-list of the italian vascularflora.Palombi ed., Roma.

Conti F., Alessandrini A., Bacchetta G., Banfi E., Barberis G., Bartolucci F., Bernardo L., Bonacquisti S., Bouvet D. ,Bovio M., Brusa G., Del Guacchio E., Foggi B., Frattini S., Galasso G., Gallo L., Gangale C., Gottlisch G., Grunanger P., Gubellini L., Iriti G., Lucarini D., Marchetti D., Moraldo B., Peruzzi L., Poldini L., Prosser F., Raffaelli M., Santangelo A., Scassellati E., Scortegagna S., Selvi F., Soldano A., Tinti D., Ubaldi D., Uzunov D., Vidali M., 2007. Integrazioni alla Checklist della flora vascolare italiana. Natura Vicentina, 10: 5-74. (2006).

di Gennaro A., 2002. I sistemi di terre della Campania. Edizioni S.EL.CA., Firenze.

FAO, 1998. World Reference Base for Soil Resources, World Soil Resources, Report No.84, FAO, Rome.

Fernandes P.M., Catchpole W.R., Rego F.C., 2001. Shrubland fire behaviour modelling with microplot data. Canadian Journal Forest Research 30: 889-899.

Fernandes P.M., Davies M.D., Ascoli D., et al. 2013. Prescribed burning in southern Europe: developing fire management in a dynamic landscape. Frontiers in Ecology and the Environment 11: e4-e14. 
Franklin S.B., Robertson P.A., Fralish J.S., 2003. Prescribed burning effects on upland Quercus foreststructure and function. Forest Ecology and Management 184: 315-335.

Greuter W., Burdet H. M. \& Long G. (eds) (1984-1989): Med-Checklist. Vols 1, 3, 4. - Conservatoire et Jardin Botaniques de la Ville de Genève, GenèveKane J.M., Varner J.M., Hiers J.K., 2008. The burning characteristics of southeastern oaks: Discriminating fire facilitators from fire impeders. Forest Ecology and Management 256: 2039-2045.

Keeley J.E., Pausas J.G., Rundel P.W., Bond W.J., Bradstock R.A. 2011. Fire as an evolutionary pressure shaping plant traits. Trends Plant Science 16(8): 406-411.

Kieft T.L., White C.S., Loftin S.R., Aguilar R., Craig J.A., Skaar D.A., 1998. Temporal dynamics in soil carbon and nitrogen resources at a grassland-shrubland ecotone. Ecology 79: 671-683.

Hutchinson T.F., 2008. Proceedings of the 3rd Fire in Eastern Oak Forests Conference. 20-22 May 2008, Illinois. General Technical Report NRS-P-46, Northern Research Station, p. 161.

Hutchinson T.F., Sutherland E.K., Yaussy D.A., 2005. Effects of repeated prescribed fires on the structure,composition, and regeneration of mixed-oak forests in Ohio. Forest Ecology Management 218: 210-228.

Maarel Van der, E., 1979. Transformation of cover-abundance values in phytosociology and its effects oncommunity similarity. Vegetatio 39: 97-114.

Mason S.L.R., 2000. Fire and Mesolithic subsistence - managing oaks for acorns in northwest Europe? Palaeogeography Palaeoclimatology Palaeoecology 164: 139-150.

Neary D.G., Gottfried G.J., Koestner K.A., Folliott P.F., Morale R.A., 2010.Burning temperatures and fire severity in cool and warm season prescribed fires and wildfire in an oak savanna of the southwestern USA. VI International Conference on Forest Fire Research, Coimbra (PT), D. X. Viegas (Ed.): 1-14.

Nicolai V., 1986. The Bark of Trees: Thermal Properties, Microclimate and Fauna Oecologia 69(1): 148-160.

Peterson D.W., Reich P.B., 2001. Prescribed fire in oak savanna: fire frequency effects on stand structure and dynamics. Ecological Applications 11(3): 914-927.

Pignatti S., 1982 - Flora d'Italia. 1-3. Edagricole, Bologna

Podani J. (2001): SYN-TAX 2000. Computer programs for data analysis in ecology and systematics. User'smanual. Scientia Publ., Budapest

Robin V., Nelle O., 2014. Contribution to the reconstruction of central European fire history, based on the soil charcoal analysis of study sites in northern and central Germany. Vegetation History and Archaeobotany.doi:10.1007/s00334-014-0438-2.

Shumway D.L., Abrams M.D., Ruffner C.M., 2001. A 400-year history of fire and oak recruitment in an old-growth oak forest in western Maryland, USA. Canadian Journal of Forest Research 31: 14371443.

Simard A.J., Eenigenburg J.E., Adams K.A., Nissen R.L., Deacon A.G., 1984. A general procedure for sampling and analyzing wildland fire spread. Forest Science 30: 51-64.

Springer U., Klee J., 1954. Prüfung der Leistungsfähigkeit von einigen wichtigeren Verfahren zur Bestimmung des Kohlemstoffs mittels Chromschwefelsäure sowie Vorschlag einer neuen Schnellmethode. Z. Pflanzenernähr. Dang. Bodenk 64: 1.

Tecimen H.B, Sevgi O., 2011. Heating induced changes in mineral nitrogen and organic carbon in relation with temperature and time. Journal of Environmental Biology 32: 295-300.

Vance E.D., Brookes P.C., Jenkinson D.S., 1987. An extraction method for measuring soil microbial biomass C. Soil Biology \& Biochemistry 19: 703-707.

USDA Natural Resources Conservation Service, 2004. In: Burc, R. (Ed.), Soil Survey Laboratory Methods Manual. Soil Survey Investigations Report No. 42, Version 4. 0. National Soil Survey Center, Lincoln, NE. 
Wang G.G., Van Lear D.H., Bauerle W.L., 2005. Effects of prescribed fires on first-year establishment of white oak (Quercus alba L.) seedlings in the Upper Piedmont of South Carolina, USA. Forest Ecology and Management 213: 328-337.

Williams R.J., Hallgreen S.W., Wilson G.W.T., 2012. Frequency of prescribed burning in an upland oak forest determines soil and litter properties and alters the soil microbial community. Forest Ecology and Management 265: 241-247. 